\title{
Leveraging Economy through MSMEs: Recent Trends and Challenges of Women's Entrepreneurship in South India
}

\section{Nisha K. M1 and Mohd Asif Khan}

\begin{abstract}
The new millennium is seen as an epoch of entrepreneurship with entrepreneurs perceiving novel opportunities, organizing resources, undertaking risks to pursue their goals in establishing innovative ventures for scaling new horizons. Women entrepreneurs have the potency to confront numerous challenges, such as creating equity, equilibrium, ensuring sustainable and inclusive socio economic development in divergent economies, by seizing tremendous business opportunities in the contemporary commercial world. Kerala, the southern State of India, is experiencing an economic renovation through technological transformation and, in particular, through the growth of women oriented Micro, Small and Medium Enterprises (MSMEs). The study aims to; identify the growth trends of women's entrepreneurship in the micro enterprises of Kerala; examine whether women's entrepreneurial activities significantly vary across the form of women owned enterprises, type of organization and nature of activity; and also explore the prospects and challenges faced by women entrepreneurs through micro entrepreneurial activities. Research methodology involves the application of descriptive quantitative analysis on the secondary data primarily collected from the database of Directorate of Industries and District Industries Centre for a period of 7 years extending from 2007-08 to 2013-14. Findings reveal that MSMEs spawn better income distribution, by operating in heterogeneous areas of the economy with limited capital and creating more employment opportunities, thereby reducing poverty and inequalities. The trend analysis reflects an escalation in the number of enterprises, investments, profits and employment opportunities generated especially through micro enterprises of women. They play a crucial role in the economy in terms of creating self employment and generating employment opportunities for others. A paradigm shift is seen in the role of women's entrepreneurship in terms of innovation, attitudes, leadership qualities, competitiveness, entrepreneurial skill and absorbing new entrants to the job market, empowering marginalized women.

Keywords: women's entrepreneurship, micro enterprises, micropreneurs, MSMEs.
\end{abstract}

1 Nisha. K.M, Ph.D., Department of Commerce, Aligarh Muslim University, Koyas Puthanarakkal Parappur (Post), Kottakkal Malappuram (District), 676503, Kerala (State), India Uttar Pradesh, India. E-mail: nishakm100@yahoo.com. 2 Mohd Asif Khan, Associate Professor, Department of Commerce, Aligarh Muslim University, Koyas Puthanarakkal Parappur (Post), Kottakkal Malappuram (District), 676503, Kerala (State), India Uttar Pradesh, India. E-mail: asif.com.amu@gmail.com. 


\section{INTRODUCTION}

Entrepreneurial development is a panacea for socio economic setbacks, poverty anomalies and lopsided development of several economies worldwide. It facilitates holistic sustainable development through rapid industrialization, mass employment generation and value addition of products and services. Empirical studies at a global level manifest that the countries with lower levels of development, greater income inequality and considerable levels of unemployment, reflected a noteworthy increase in entrepreneurial activities. Entrepreneurship is more necessity-driven in backward and developing economies. On the contrary, in countries with relatively low income, inequality, and low unemployment i.e., the more developed nations, the rates of entrepreneurial activities are significantly lower. Their economies are characterized by opportunity and innovation driven entrepreneurs (Kelly, Brush, Greene \& Litovsky, 2010; Reynolds, Camp, Bygrave, Autio \& Hay, 2002). Infrastructural development, financial access, regional policies, and the availability of quality labour and technological resources are the predominant factors influencing the development of Small and Medium Enterprises (SMEs) universally (Luczka \& Pzepiora, 2012). Gancarczyk and Zabala-Iturriagagoitia (2015) inferred that the capacity to sense, comprehend, filter, shape and calibrate opportunities is a decider of SMEs growth. The investigation threw light on the facts that configuration, procedures, designs and incentives to seize opportunities, investment structure of the units, education and training of human resource, influence the growth process of SMEs.

India, basically an agrarian economy, has been on the slower side with regard to industrialization and economic growth. With the advent of new industrial and economic policies and its impacts, India is emerging as one of the fastest growing economies in the world, showing signs of growth particularly in entrepreneurial development. MSMEs are becoming the beacon for the development of new entrepreneurial talents and innovation which are heterogeneous and widely dispersed across the country. Revitalizing inclusive growth of small businesses is decisive for income generation, job creation and self-employment opportunities for millions of prevailing and potential entrepreneurs, and ensuring optimum utilization of available resources in the country. The unorganized sectors of MSMEs in India are more than those in the organized sectors. The enactment of the MSME Development Act of 2006, enthused more and more enterprises to become registered under this Act, gradually facilitating the units to be a part of the organized segment. The manufacturing enterprises of MSMEs are more than the service sector enterprises in the country. Micro enterprises alone have a substantially higher share (more than $85 \%$ ) of the total MSME sector in India. They are producing and marketing multiple ranges of products and services to 
meet the variant needs of the local, domestic and global markets or value chains (Micro Small and Medium Enterprises [MSME], 2015).

Over the past few decades there has been a change in the socio economic scenario with the burgeoning participation of women in entrepreneurial activities. In the business life cycle, women are progressively crossing socio cultural and economic barriers, integrating their knowledge, skills and competencies to bring resilience to their business and economy as a whole (Ascher, 2012). Women's entrepreneurship, especially in the MSMEs, can kindle the share of the overall manufacturing and service sector by providing adequate support and patronage to small scale industries in formal and informal segments. Such enterprises are indispensible in terms of inclusive, equitable and balanced development, through the creation of employment opportunities, technological upgradation, upholding the entrepreneurial spirit and innovation at regional, national and international levels. The MSME sectors are a gateway to global growth in India and Kerala, the southernmost State in the country, is making remarkable strides towards being one of the main hubs for stimulating women's entrepreneurial growth and development.

Kerala has been facing a lot of hardships in the industrial arena and its industrial policies of 2001 and 2007 have been the rationale for many structural changes in the region. Despite various impediments, the State has registered the highest growth rate in MSMEs among the South Indian States in recent years. The MSME sector in the State has been dynamically contributing towards domestic needs, export marketing and foreign exchange earnings, by manufacturing and marketing divergent products and services, ranging from traditional to modern ones. Kerala is also the leading state in India, with the largest number of women micropreneurs. Microenterprises, having a higher share among the MSMEs in the State, are the seedbeds for stimulating broader development throughout the economy by providing a strong base. They are an attractive alternative for providing wider access, easy start ups with lesser investment, use of traditional technology, lesser risk and, above all, the capability of establishing home based industries. The present study attempts to investigate the role of women's entrepreneurship in leveraging the economy through registered microenterprises of MSMEs in South India with special reference to Kerala.

\section{BACKGROUND OF THE STUDY}

\section{Women's entrepreneurship}

Women's entrepreneurship in the globalization eon, acts as a catalyst for economic development and aids in creating new business women with substance, strength, and better managerial and decision making skills. 
Women's entrepreneurship comprises of a woman or a group of women who discover new ideas, establish innovative venture, organize the factors of production such as labor, material, money, information and other resources, exploit opportunities in the market, create jobs and undertake risks, all in return for making a profit. Although there has been an encouraging upsurge in the number of women entrepreneurs across the globe in recent years, they are still underrepresented when compared to male entrepreneurs. Besides, they generally choose a line of business or industry that is contributing less to economic performance, like retail distribution, education and other service sectors. On the contrary, men are generally focused on manufacturing and high technology oriented activities that are highly productive and growth oriented. Women in the modern business world have to go a long way ahead, focusing more on key industrial and service sectors that have a greater potential of fetching higher returns and better opportunities for rapid and unwavering growth. Recently, women have been liberating themselves from the clutches of their stereotypical role and exploring new vistas of economic involvement, with broader vision and perseverance in their stride towards superior business accomplishments.

LPG, economic crises, social problems, the need for economic selfreliance, etc., are stimulating brand new entrepreneurial styles among women entrepreneurs, with diverse areas of interest ranging from designers, interior decorators, exporters, publishers, garment manufacturers, catering service providers, fisheries, agriculture, etc. A new entrepreneurial culture is emerging in the field of women's entrepreneurship based on creativity, self reliance, cooperation and openness. It is gradually making them economically productive members of the country who can contribute significantly to the income and wealth of the family and nation as a whole. Women, via entrepreneurial talents, are venturing into multi faceted business activities to improve their livelihood and self-esteem, obtain freedom from oppression and enjoy greater choices, thereby improving their standard of living at familial, societal, national, as well as international, levels. Channelizing women into the mainstream is both morally and economically essential for removing the gender gap and establishing fairness and equity, the realization of individual aspirations, socio economic empowerment and ensuring a better standard of living for all.

\section{Overview of micro small and medium enterprises in India}

The Industries Development and Regulation Act (IDRA), 1951, laid the foundation for developing a conceptual and legal framework for small scale and ancillary industrial undertakings in India. The SMEs Development Bill, 
2005 paved the way for the enactment of the MSMED Act, 2006 and it became operational throughout India from 2nd October, 2006, replacing the concept of 'Industry' with 'Enterprises'. In 2007 the Government of India merged the former Ministry of Small Scale Industries and the Ministry of Agro and Rural Industries to form the Ministry of MSMEs. The Ministry now designs, promotes, facilitates, implements and monitors various programmes, projects and schemes with the aim of assisting MSMEs and helping them to scale up. The MSMED Act was notified in 2006, to address policy issues and strategies affecting MSMEs, and the coverage and investment ceiling of the sector. Although the primary responsibility for the promotion and development of MSMEs is vested with the State Governments, the Centre supplements the efforts of the State Governments through various initiatives (MSME, 2014). MSMEs differ in size and scope in different countries and the parameters on which the SME sector is generally defined is based on capital investment in plant and machinery, on the number of workers employed, or on the volume of production or turnover of the business. In India, MSMEs are defined in terms of the size of investment they employ in the plant and machinery or in equipment.

Table 1. Definition of MSMEs according to MSMED Act 2006

\begin{tabular}{|c|c|c|}
\hline \multirow{2}{*}{ Enterprise } & Manufacturing Sector & Service Sector \\
\hline & (Investment in Plant and Machinery) & (Investment in Equipment) \\
\hline Micro & Does not exceed Rs. 25 Lakhs & Does not exceed Rs. 10 Lakhs \\
\hline Small & $\begin{array}{l}\text { More than Rs. } 25 \text { Lakhs but does not } \\
\text { exceed Rs. } 5 \text { Crores }\end{array}$ & $\begin{array}{l}\text { More than Rs. } 10 \text { Lakhs but does not } \\
\text { exceed Rs. } 2 \text { Crores }\end{array}$ \\
\hline Medium & $\begin{array}{l}\text { More than Rs. } 5 \text { Crores but does not } \\
\text { exceed Rs. } 10 \text { Crores }\end{array}$ & $\begin{array}{l}\text { More than Rs. } 2 \text { Crores but does not } \\
\text { exceed Rs. } 5 \text { Crores }\end{array}$ \\
\hline
\end{tabular}

Source: MSME (2016).

As per the reports of Inter-Ministerial Committee for Accelerating Manufacturing in the MSME Sector, Lal (2013), states that MSMEs contribute to nearly $8 \%$ of India's GDP, $45 \%$ of the manufacturing output and $40 \%$ of the nation's exports. MSMEs are the largest employment generators in the country after agriculture. Press Information Bureau, MSME estimated that the contribution of the manufacturing sector of MSME to GDP during 201213 , was $7.04 \%$ and the services sector MSMEs contributed $30.50 \%$ to Indian GDP. During 2012-13, the share of the MSME sector in the GDP of the country in total accounted for 37.54\% (Micro Small and Medium Enterprises, Press Information Bureau [MSME PIB], (2014). 


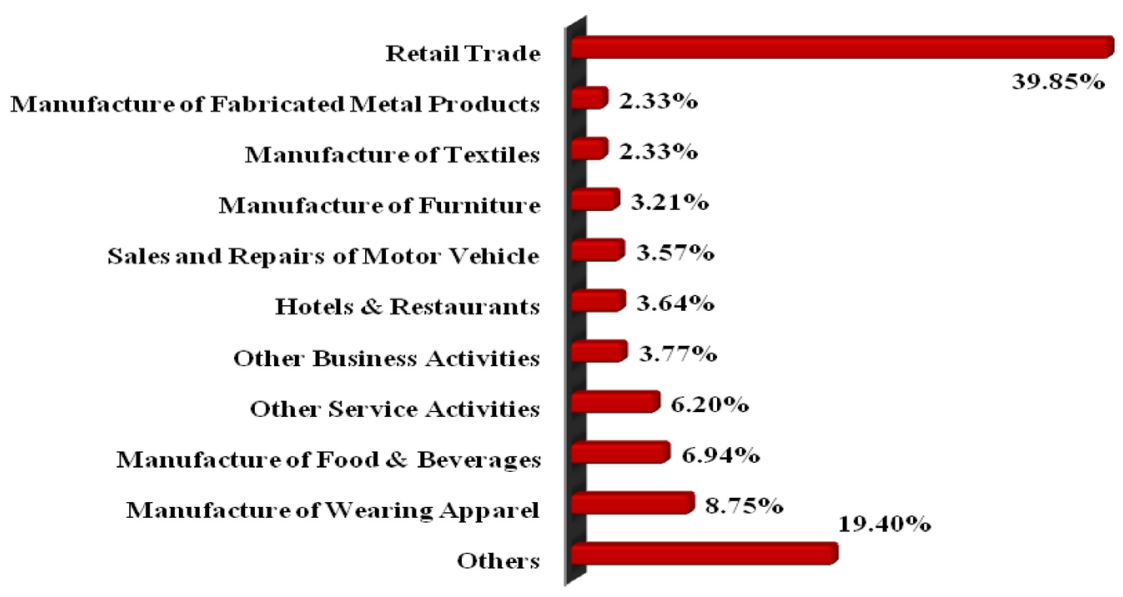

Figure 1. Leading Industries of MSME Sector

Source: MSME (2014)

Figure 1, depicts the leading industries with their respective shares. In India, the MSME sector is highly active in the retail trade with a share of $39.85 \%$ of the total MSME products and services (excluding motor vehicles and motor cycles, repairs of personal and household goods). The contribution of wearing apparel; dressing and dyeing of fur is $8.75 \%$ and for manufacturing of food products and beverages the share is $6.94 \%$. The percentage share for hotels and restaurants is 3.64\% and it is 3.57\% for sale, maintenance, repairs of motor vehicles and motor cycles. As per the recent statistics published in the annual report of MSME (2014), over 6000 products, ranging from traditional to high-tech items, are being manufactured by the MSME sector, besides providing a wide range of services.

\section{Recent developments of women's entrepreneurship in South India with emphasis on MSMEs in Kerala}

Development will be disproportionate if women's entrepreneurial activities are ignored. With women constituting more than half the population, given a better environment and more opportunities to flourish, they can bring a radical change to the economic development activities of the State. Women have vast potencies but they still linger as an untapped and underutilized human resource worldwide. In Kerala too, the scenario is not different, with women's development not in parity with that of their male counterparts throughout various sectors of the economy. MSMEs can act as an imperative instrument for the development of women and realize the goals of economic 
growth and development of any nation. The MSME spectrum includes highly innovative, fast growing enterprises using hi-technologies that are more capital intensive, while at the other end lie micro businesses carried on by entrepreneurs typically on traditional lines using conventional methods which are more home-based and labor intensive. It has been observed that most of the MSMEs in Kerala are concentrated in the informal sectors that are unregistered and unorganized. The State government needs to introduce extra initiatives to encourage these more informal sectors to become registered under the MSMEs Act, so that a more structured form of business will be evolved that can enhance the organized, planned and systematic development of entrepreneurship in the country.

MSMEs are displaying entrepreneurial fortitude by emerging as a vibrant income generating and employment providing sector, predominantly in the Kerala economy. Buoyancy in the entrepreneurial sector, particularly through women's entrepreneurship, can traverse the wave of industrial boom in south India, as the State of Kerala is already in the forefront with respect to literacy, health care, women welfare, infrastructural development, and with respect to highly educated human capital of the country. As per the latest statistics available Kerala has a growth rate of $8.24 \%$ in MSMEs, which is much higher than the National average of $5 \%$, with a major contribution flowing from the service sectors. The State, in the post liberalization period, has been registering remarkable growth in secondary and tertiary sectors and is persistently in the forefront with respect to social development. It has made brisk progression in the field of Information Technology, Tourism and Hotel Industry, Research and Development, Agribusiness, Food Processing Industry, Entertainment, Internet and Mobile Services, Banking, Insurance and so on (Department of Industries and Commerce, 2015).

More than 50,000 registered micro enterprises are now functioning in the rural, semi urban, as well as in urban areas across the State. They are engaged in diverse manufacturing and service sectors like the manufacturing of dairy products, food processing, readymade garments, soap and paper bag making, catering services, courier services, preparation of ethnic delicacies, etc. Initiatives have been taken for the development of the MSME sector and protecting the traditional industries through Private Public Partnership (PPP) arrangements. Funds and allied resources have been allocated to the construction of more hi-tech incubators, industrial parks, to provide training for skilled man power, development of clusters and a focus on product diversification to cater for varied customer requirements. Measures have also been taken for the rejuvenation of traditional and ethnic sectors like Handloom Societies, Hantex, Handweave, Powerloom Societies and development of a Handloom Village. Endorsement of value added products, 
providing margin money loans and grants to ensure financial inclusion, and the free flow of funds for smooth entrepreneurial operations, are also given due importance. Other priorities include the stimulation of Coir Industry, increasing the production in Khadi and Village Industrial sector, renovation of Cashew sector including its brand building programmes (State Planning Board, 2013). This paper examines the following research questions:

1) Does women's entrepreneurship show positive growth trends in micro enterprises of MSMEs in Kerala with respect to total investment, annual turnover, export value, and employment generation?

2) Are women's entrepreneurial activities significantly varied across the form of women enterprises, type of organization, and nature of activity?

3) What are the prospects and challenges faced by women entrepreneurs through micro entrepreneurial activities in Kerala?

The purposes of the study are as follows:

1) To analyze the growth trend of women's entrepreneurship in micro enterprises of MSMEs in Kerala with respect to total investment, annual turnover, export value and employment generation

2) To examine whether women's entrepreneurial activities significantly vary across the form of women enterprises, type of organization and nature of activity

3) To explore the prospects and challenges faced by women entrepreneurs through micro entrepreneurial activities in Kerala.

\section{RESEARCH METHODOLOGY AND DESIGN}

An exploratory design was adopted in the initial stages of the research i.e., while reviewing literature of empirical and conceptual in nature. Descriptive design of quantitative nature has also been used while analyzing the secondary data that was primarily collected from the database of Directorate of Industries (DIs), District Industries Centre for the period extending from 2007-08 to 2013-14. Although unorganized sectors of MSMEs are more than organized sectors, due to a lack of availability of authentic data related to the unorganized sectors in Kerala, only the MSMEs registered under MSMED Act of 2006 in the State have been considered for the study. In addition, various reports of International Organizations and data drawn from records and various publications of the central, state and local governments have been used. Online publications on websites of government and NGOs and data from financial and other records of enterprises established by women have been utilized in the research. It also included data and information gathered from various books, articles, journals, reports, magazines, newspapers, theses and dissertations of both Indian and foreign publications that are pertinent to the study. 


\section{RESULTS AND DISCUSSION}

\section{Trends in women owned micro enterprises of Kerala since MSMED Act, 2006}

Over the last few decades there has been a phenomenal overhaul in the arena of women oriented business. The status of women in India, their working conditions and state of affairs, are gradually improving from being just home makers and job seekers to a higher echelon of job creators. MSMEs' registered units in Kerala for a period of 7 years extending from 2005-06 to 2012-13 are the main area of focus in the present study. The MSME Development (MSMED) Act was enacted during 2006 and, in the initial periods of the enactment of the Act, MSMEs also includes registered SSI units, i.e., between the periods 2005-06 to 2007-08. As per the All India census reports, comparative trends within India shows that Tamil Nadu has the highest number of enterprises followed by Kerala and Karnataka, all these being southern States of India. However, women entrepreneurs in the organized sectors of MSMEs registered under MSMED Act of 2006 are lesser as compared to the unorganized sectors. All India statistics on MSMEs also depict that, out of all female enterprises, $98 \%$ are micro enterprises, $1.80 \%$ come under the category of small and only $0.05 \%$ are medium enterprises (Shah, 2013).

$\mathbf{1}$
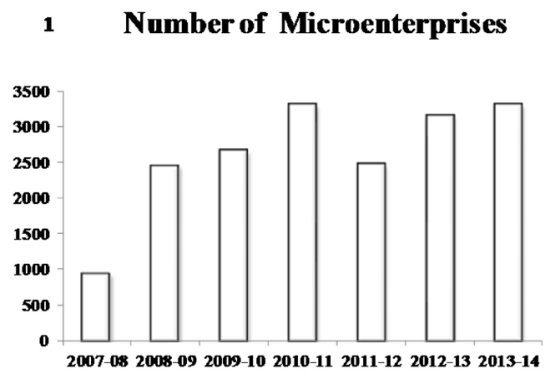

$\mathbf{2}$

Export Value
3
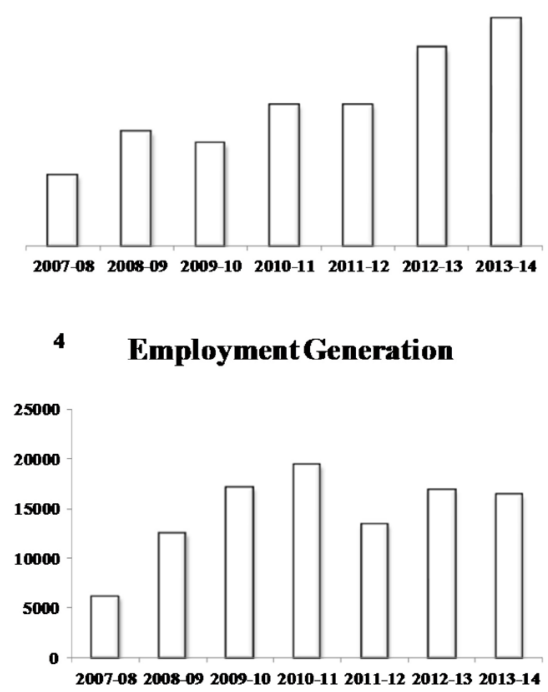

4 EmploymentGeneration

2007-08 2008-09 2009-10 2010-11 2011-12 2012-13 2013-14

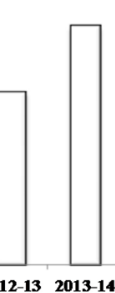

Total Investment

Figure 2. Trends in women owned enterprises from 2007 to 2014 Source: Directorate of Industries and Commerce (2014) 
Figure 2, illustrates the particulars of various economic indicators related to women entrepreneurs in micro enterprises of Kerala in terms of the number of micro enterprises, total investment, employment generation and export value. It depicts the trends over a period of 7 years starting from 200708 to 2013-14. The figure related to the number of micro enterprises signifies that it increased steadily except from the year 2011-12 onwards. The export values of women micro enterprises in the initial years are lesser but towards the later stages it starts increasing noticeably. Total investment values also demonstrate that there has been a gradual mounting trend. The employment generated through women micro enterprises rises slowly and subsequently declines during 2011-12 then after it depicts stable growth in the years 201213 and 2013-14. During the financial year 2011-12 it is evident that there was a decline in the number of micro enterprises, total investment, employment generation and export value mainly due to the impacts of economic crises and depression in the domestic market.

Table 1. Details of Growth Rate of Various Economic Factors of Women's entrepreneurship in Micro Enterprises of Kerala from 2007-08 to 2013-14

\begin{tabular}{lcrrrrr}
\hline Year & \multicolumn{7}{c}{ Total Investment * AGR (\%) Annual Turnover AGR (\%) } & \multicolumn{1}{l}{ Export } & AGR (\%) \\
\hline $2007-08$ & 806143086 & & 1384458641 & & 52160000 & \\
$2008-09$ & 1307921230 & 62.24 & 2488035436 & 79.71 & 27463335 & -47.35 \\
$2009-10$ & 1174719209 & -10.18 & 3309588091 & 33.02 & 28321199 & 3.12 \\
$2010-11$ & 1615098093 & 37.49 & 183799101259 & 5453.53 & 63412441 & 123.90 \\
$2011-12$ & 1619583649 & 0.28 & 4015996684 & -97.82 & 20867646 & -67.09 \\
$2012-13$ & 2265900582 & 39.91 & 4625686837 & 15.18 & 123150000 & 490.15 \\
$2013-14$ & 2597209841 & 14.62 & 15665928956 & 238.67 & 170250015 & 38.25 \\
\hline
\end{tabular}

* Annual Growth Rate $(A G R)=((X 2-X 1) / X 1) * 100$, where, $X 1=$ first value of variable $X$ and $X 2=$ second value of variable $X$.

Source: Directorate of Industries and Commerce, Kerala and compiled by the Author.

Table 1 , shows the details of women entrepreneurs in micro enterprises in Kerala with respect to Total Investment, Annual Turnover and Export. On an overall basis it is evident that the figures for total investment, annual turnover and export value of MSMEs are more or less reflecting a rising trend. The table clearly depicts the Annual Growth Rates of MSMEs from 2007-08 to 2013-14. The annual growth rate of total investment of women entrepreneurs in micro enterprises is showing a fluctuating trend over the years as compared to the immediately preceding years. During 2008-09 the AGR of total investment was $62.24 \%$ and then fell to negative figures in the year 2009-10. Later it reflected a mixed trend with the growth rate rising and dipping alternatively. In the case of annual turnover, the growth percentage 
gives evidence that it is highly fluctuating over the periods considered for study. It was highest during 2010-11 and lowest in the year 2011-12. The annual growth rate of export shows that it has a peak growth rate in the year 2012-13 and negative AGR during the periods 2008-09 and 2011-12.

Table 2, demonstrates the details of types of women's enterprises of MSMEs in Kerala during 2007-08 to 2013-14. It reveals that there are more women owned and managed micro enterprises in Kerala as compared to small and medium enterprises. The annual growth rate of micro enterprises was highest during 2008-09 and there is a negative annual growth rate of $-25 \%$ in 2011-12. Small enterprises showed a growing trend from 2008-09 to 2010-11. However, it plunged to negative figures in 2011-12.

Table 2. Details of Growth Rate of Types of Women Enterprises of MSMEs in Kerala during 2007-08 to 2013-14

\begin{tabular}{lrrrrrrrr}
\hline Year & Micro & AGR (\%) & Small & AGR (\%) & Medium & AGR (\%) & Total & AGR (\%) \\
\hline $2007-08$ & 942 & & 44 & & 0 & & 986 & \\
$2008-09$ & 2455 & 161 & 50 & 14 & 2 & 0 & 2455 & 149 \\
$2009-10$ & 2667 & 9 & 63 & 26 & 1 & -50 & 2667 & 9 \\
$2010-11$ & 3309 & 24 & 80 & 27 & 1 & 0 & 3390 & 27 \\
$2011-12$ & 2475 & -25 & 73 & -9 & 1 & 0 & 2549 & -25 \\
$2012-13$ & 3152 & 27 & 75 & 3 & 2 & 100 & 3229 & 27 \\
$2013-14$ & 3313 & 5 & 81 & 8 & 0 & -100 & 3394 & 5 \\
\hline
\end{tabular}

Source: Directorates of Industries and Commerce, Kerala and compiled by the Author.

Table 2, also shows that in succeeding years it showed positive signs of recovery but with lower growth rates in comparison to early years. The contribution of medium enterprises to the total number of registered MSMEs is meager having only one enterprise on average over the period of seven years. The latest figures indicate that micro enterprises constitute about 98\% of units in MSMEs. Only 2\% of enterprises are small and there are no medium enterprises registered during the year 2013-14.

Figure 3, displays that the proportion of micro enterprises is much higher than the other forms of enterprises in MSMEs. It is followed by small enterprises and finally medium enterprises having limited number of units. It is also apparent from the figure that micro enterprises are showing an upward shift over the period of seven years, except in 2011-12. Micro enterprises are greater in number because the majority of the women entrepreneurs fall under the category of low or middle income groups. Above all, they can easily be operated as home based industries in urban or rural areas with lesser risk, 
simpler technology, lesser capital, with locally available resources, and they can be run on traditional lines.

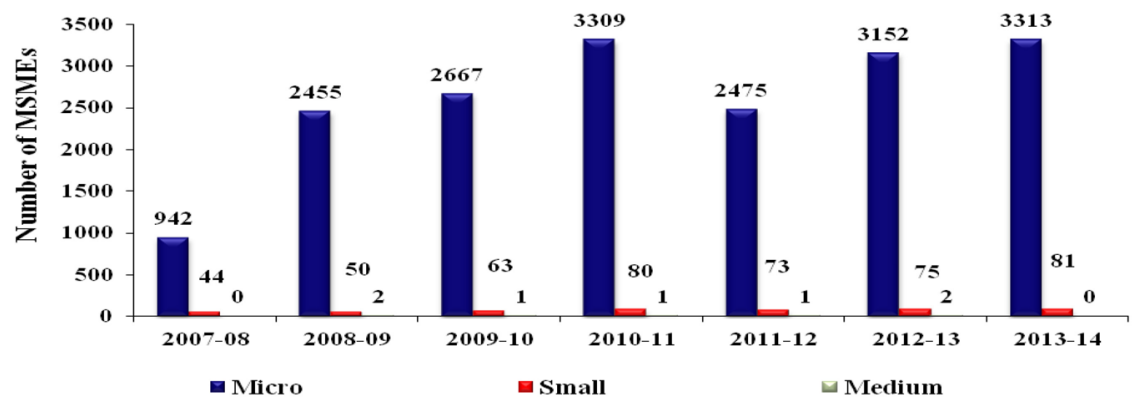

Figure 3. Trend of Growth of Women Entrepreneurs in MSMEs of Kerala from 2007-08 to 2013-14

Table 3. Details of types of organization owned by women in MSMEs in Kerala during 2007-08 to 2013-14

\begin{tabular}{|c|c|c|c|c|c|c|c|c|c|c|}
\hline 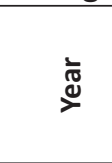 & 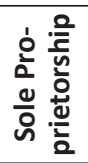 & $\frac{\grave{O}}{\frac{0}{4}}$ & 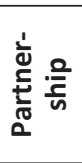 & $\frac{\stackrel{Ð}{0}}{\frac{0}{4}}$ & $\begin{array}{l}\text { ড় } \\
\text { ডે }\end{array}$ & $\frac{\text { }}{\frac{0}{00}}$ & $\begin{array}{l}\frac{n}{d} \\
\frac{5}{5} \\
0\end{array}$ & $\frac{\overparen{d}}{\frac{0}{0}}$ & 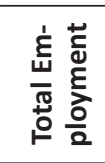 & $\frac{\widehat{d}}{\frac{0}{0}}$ \\
\hline 2007-08 & 785 & & 42 & & 41 & & 74 & & 6138 & \\
\hline 2008-09 & 2245 & 185.99 & 45 & 300 & 109 & 166 & 56 & -24 & 12529 & 104 \\
\hline 2009-10 & 2405 & 7.13 & 74 & 2900 & 129 & 18 & 59 & 5 & 17136 & 37 \\
\hline 2010-11 & 3083 & 28.19 & 89 & 1500 & 87 & -33 & 50 & -15 & 19413 & 13 \\
\hline 2011-12 & 2288 & -25.79 & 62 & -2700 & 78 & -10 & 47 & -6 & 13424 & -31 \\
\hline $2012-13$ & 2851 & 24.61 & 75 & 1300 & 143 & 83 & 83 & 77 & 16921 & 26 \\
\hline 2013-14 & 3141 & 10.17 & 80 & 500 & 60 & -58 & 32 & -61 & 16381 & -3 \\
\hline
\end{tabular}

Source: Directorates of Industries and Commerce, Kerala and compiled by the Author.

Table 3, displays the type of organization owned and managed by women in MSMEs in Kerala during the 7 years period. As compared to the base year 2007-08 there has been a significant increase in the number of women entrepreneurs in MSMEs during 2013-14 and also the total employment opportunities created by these units. The proportion of sole proprietorship type of units in the MSMEs' structure is much higher than in partnership, Self Help Groups (SHGs) or other forms of enterprises. Results of annual growth rate over the previous year periods indicate that sole proprietorship 
units have the highest growth rate of $185.99 \%$ in $2008-09$ and the lowest and negative rate during 2011-12. Partnership and SHG type of units register erratic growth rates with a higher rate of growth in the initial years and a diminishing trend towards later stages. The table also throws light on the employment opportunities created by women run micro enterprises. It generates employment of 6,138 in the year 2007-08 and the statistics reflect that employment generation has increased to a level of 16,381 employees during the year 2013-14. Employment growth is at its maximum in women based micro enterprises during 2008-09 and later in 2011-12 it falls to a negative figure of $-31 \%$. The AGR improves slightly in subsequent years but again dips to negative figures in 2013-14. In general it has been inferred that over the period of 7 years considered, the number of women oriented enterprises in different sectors and employment generation through these enterprises, are demonstrating an intensifying trend. However, while considering their annual growth rates over the immediate previous years, it shows that the percentage of growth keeps fluctuating.

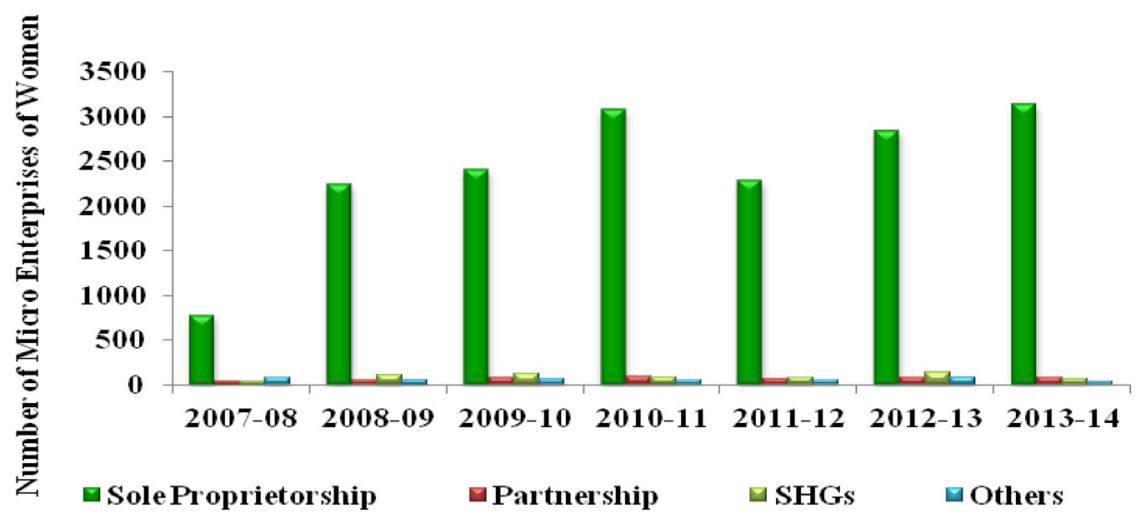

Figure 4. Trend of women entrepreneurs in micro enterprises based on type of organization from 2007-08 to $2013-14$

Figure 4, indicates the trend of women entrepreneurs in micro enterprises, based on type of organization from the period 2007-08 to 201314. Among the various organization types, sole proprietorship has the highest proportion of units followed by SHGs and partnership form of business and others including cooperative societies, private and public limited companies and Hindu Undivided Families. Over the period of 7 years the different forms of micro business owned and managed by women entrepreneurs show a growing pattern. However, there is a slight decrease in the growth during 2011- 
12. In the following years i.e., 2013 to 2014, the growth again demonstrates an escalating trend. During the year 2013-14 the sole proprietorship form of business has the highest majority as it constitutes $95 \%$ units in MSMEs. Partnership and SHGs accounts for only $2 \%$ each and the other categories, comprising of cooperative societies, private and public limited companies and Hindu Undivided Families, has a meager share of $1 \%$.

Table 4. Details of women oriented micro enterprises based on nature of activity during 2007-08 to 2013-14

\begin{tabular}{lcccc}
\hline Year & $\begin{array}{c}\text { Manufacturing } \\
\text { Sector }\end{array}$ & AGR (\%) & Service Sector & AGR (\%) \\
\hline $2007-08$ & 869 & --- & 73 & ---- \\
$2008-09$ & 2094 & 140.97 & 361 & 394.52 \\
$2009-10$ & 2332 & 11.37 & 335 & -7.20 \\
$2010-11$ & 2927 & 25.51 & 382 & 14.03 \\
$2011-12$ & 2070 & -29.28 & 405 & 6.02 \\
$2012-13$ & 2531 & 22.27 & 621 & 53.33 \\
$2013-14$ & 2518 & -0.51 & 795 & 28.02 \\
\hline
\end{tabular}

Source: Directorates of Industries and Commerce, Kerala and compiled by the Author

Table 4, indicates the particulars of women oriented micro enterprises in Kerala based on their nature of activities for the period extending from 2007-08 to 2013-14. The AGR of manufacturing and service sector over their previous years shows fluctuating growth. The AGR is highest in the manufacturing sector during the year 2008-09 with 140.97\% growth over the immediately preceding year. It is lowest and negative with a rate of $-29.28 \%$ in the year 2011-12. In the case of the service sector the AGR is highest in 2008-09 with a rate of $394.52 \%$ and lowest at $-7.20 \%$ in $2009-10$. In the year $2013-14,76 \%$ of the working units that are women oriented come under the manufacturing sector and only the rest $(24 \%)$ are related to the service sector.

The major manufacturing activities undertaken by women entrepreneurs in the study area include garment making, preparation of handloom clothes, producing and processing of food items like pickles, bakery products, running flour and oil mills, manufacture of tiles and hollow bricks, soap and washing powers, bags, umbrella and candle making, preparation of bamboo products, book binding and printing press etc. Among these categories garment making and food processing were in the forefront. Service based activities include running hotels, catering services, operating day care centres, beauty clinics, textile shops, computer centres, interior decoration services, construction services etc. Service sector enterprises of women entrepreneurs in Kerala are dominated by textile shops, beauty clinics, IT and catering services. 
The study also found that the majority of women entrepreneurs in the organized sectors of MSMEs started their enterprises with the aim of earning a livelihood or supporting their family, and that they were more necessity driven entrepreneurs rather than opportunity or innovation driven (Nisha, 2015).

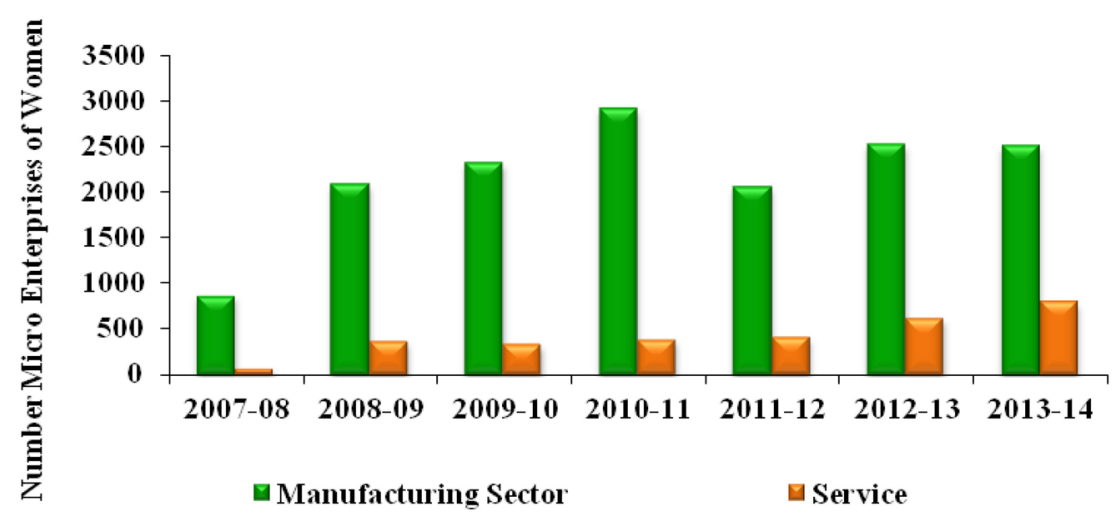

Figure 5. Distribution of women entrepreneurs in manufacturing and service sectors of micro enterprises of Kerala from 2007-08 to 2013-14

The trend of growth in the number of manufacturing and service sectors of women owned micro enterprises are reflected in Figure 5. It points to evidence which indicates that the number of manufacturing enterprises is more than the number of service sector enterprises. The manufacturing sector MSMEs are showing rising trends as growth proceeds from 2007-08 to 2010-11. In 2011-12 it drops and later starts rising in 2012-13 to 2013-14. The service sector enterprises are showing a more or less steady increase in the growth of number of enterprises. However, a review of annual reports of MSMEs provides the evidence that the income generated by service sector MSMEs is much higher than the service sector MSMEs in the country, thereby contributing significantly to GDP in India.

\section{Prospects and challenges of women's entrepreneurship}

\section{Prospects}

Attracting more investments: In order to attract more investments in MSMEs, importance is given to the Private Public Partnership (PPP) model 
of development. Other policy measures of the Government include increasing land pooling facilities, promotion of industrial estates or parks and entrepreneurial development through industrial clusters. Ample steps are also taken for accelerating developmental activities through the promotion of Special Economic Zones in tune with National Manufacturing Policy. Creation of a MSME Equity Participation Fund through KSIDC and KFC to encourage startups is also underway (Department of Industries and Commerce, 2015).

Industrial Development Zones (IDZ): Measures are underway in building up IDZ for the promotion of manufacturing industries, agro based industries, textiles, commercial ventures, gems and jewellery products and social infrastructure. As a part of encouraging women's entrepreneurship in the State, the government considers treating women based industries under the category of thrust industry and authorizes them to avail of $30 \%$ investment subsidies. The thrust sector industries in the State are eligible for a higher rate of investment subsidies. They include rubber based industries, agribusiness covering food processing, marine products, ayurvedic medicines, readymade garments, light engineering, bio and nano technology and 100\% export oriented units.

Boosting self employment opportunities: The Kerala State Entrepreneurs Development Mission was an initiative launched by the Government, which endeavored to provide self employment to 1 lakh youths of the State through establishing 10,000 new ventures, over a period of 5 years (Micro Small and Medium Enterprises Development Institute [MSME-DI], 2012). 'WE-Mission' (Women Entrepreneurs Mission) was launched in the State to spread the spirit of entrepreneurship among women and scale up entrepreneurial activities. (Express News Service, 2015, May 08). It is proposed that a Job Bank is setup, using the name 'She Bank', employing skilled and trained women who can offer advice and financial support. An interest subvention scheme for Rs.10 Crores has been announced to cater to the needs of existing women entrepreneurs. The scheme is expected to cover industrial units run by women employing not less than $50 \%$ of women in its workforce (Express News Service, 2015, March 16).

New gen entrepreneurial development: India, having the highest youth population in the world, is targeting the young entrepreneurial talents for faster growth and better results. Having the benefit of a high Human Development Index, Kerala is budding fresh entrepreneurs to their entrepreneurial development clubs, which facilitate an evolution of new entrepreneurial culture in the State. It is the first Indian State to have earmarked $1 \%$ of the budget provision of each department for the entrepreneurship development programmes for students and youth. As part of bringing up a new generation of entrepreneurs, all Universities in Kerala have resolved to give 5 percentage 
grace marks and 20 percentage attendances to student startups, which have at least one woman as a co-founder.

Magnetizing more enterprises into the organized sector: New policy measures of the State include a simplification of regulatory procedures for the establishment and running of enterprises. Procedures for registration and licensing systems are simplified to make it more transparent and enhance easy inception and operation of women entrepreneurial units. Online filing procedures for registration are available to facilitate the easy and quick registration of MSMEs. Interest free loans, subsidies and other financial assistance, tax benefits, free training and technological aid for women entrepreneurs etc., have also been implemented by the government to support and enrich entrepreneurial activities in the registered sector.

Protection and promotion of traditional and ethnic industries: Traditional and ethnic industries of Kerala, comprising of handloom, cashew, coir, handicrafts, bamboo, khadi etc., have also been promoted through a variety of new schemes and by allocating a substantial amount of funds. Several traditional industries have been registered with the Geographical Indications Registry of India to promote them globally.

Export orientation: At international level the electronics manufacturing industry is the largest and fastest growing manufacturing segment and India's growing strength in semi-conductor chip design, Electronics Systems Design \& Manufacturing (ESDM), offers exceptional opportunities for growth and employment. The government is envisioning and giving its proactive support to the State of Kerala to become the most preferred destination for ESDM investments, and develop into a major hub for Electronics design and embedded software in India by the year 2020. The government has also decided to provide a $20 \%$ capital subsidy for innovative manufacturing units in the ESDM sector of Kerala.

\section{Challenges}

There is a dearth of financial assistance available to support women's entrepreneurship and besides this they are always the victims of exploitation by money lenders and other financial institutions who charge exorbitant rates of interest for credit. The repayment capacity of women is lower, either due to the low profits of their businesses, or a lack of financial support in the form of ownership of assets or other properties.

Women are also facing social taboos and other cultural barriers that thwart the growth and sustenance of their enterprises. Restrictions for women coming into business in certain communities and conventional social 
roles assigned to women often prove to be a handicap for women's free mobility and freedom to work (Behara \& Niranjan, 2012).

Various hurdles faced by women entrepreneurs in the current scenario include a lack of social support, the negative attitude of society towards women oriented businesses, marketing problems, a lack of availability of easy finance, paucity of raw materials, a lack of technical know-how, poor managerial skills, twofold responsibility for home and business, low risk bearing capacities and family conflicts, All these factors and more, are hampering women from coming into the business world or thwarting their performances (Vijayakumar \& Naresh, 2013).

Women entrepreneurs have to face a series of problems right from the stage of establishing an enterprise and then all through the operational stages. The critical problems faced by women entrepreneurs include sociocultural barriers, market-oriented risks, a lack of knowledge in business administration, and limited awareness about financial assistance, all blocking the way of women's entrepreneurial development (Gupta \& Kumari, 2014).

According to a United Nations Industrial Development Organization (UNIDO), (2003), report, women suffer from various constraints, and cultural values and social norms hinder the equal participation of women in society. Women entrepreneurs face problems of unequal access to productive resources and services, including finance and skill upgrading opportunities. Certain legal provisions and legislative systems make it complicated for women entrepreneurs to take business development initiatives. Their dual role of maintaining family responsibilities and being business women is another major challenge.

The challenges identified through various empirical studies and review of literature mentioned earlier is also prevalent among women entrepreneurs in MSMEs in the southern State of India. Women entrepreneurs' needs for becoming economically productive and enthusiastic can be materialized through devising pertinent measures to integrate women as decision makers, participants and beneficiaries, thereby improving their opportunities for better performance and scope for attaining higher living standards. A wide continuum of elements affects the equitable participation of women in development so it is necessary to address the totality of problems women face as entrepreneurs.

\section{CONCLUSIONS}

Women entrepreneurs, despite facing various hurdles, are spreading their wings and exploring new avenues of economic participation. The growth of women's entrepreneurship in the State has a potent multiplier effect that can 
result in healthier, better educated families and eventually greater economic augmentation. MSME sectors in Kerala have been contributing significantly towards domestic needs, export marketing and foreign exchange earnings, producing divergent products ranging from traditional to modern, with lower energy consumption and minimal damage to environment. Results, based on secondary data related to the 7 year period considered in the study, show that women's entrepreneurial activities in the registered MSMEs indicate a dominance of micro enterprises, and that the number of sole proprietorship type of units in the MSMEs' structure is much higher than in partnership, SHGs or other forms of enterprises. It can also be seen that the number of manufacturing enterprises is more than service sector enterprises. The trend analysis result portrays a rising trend in the number of enterprises, investment, profit and employment opportunities, all revealing the future prospects for women's entrepreneurship in the State. Women play a foremost role in the prosperity of a society, and with Kerala being the only State in India having a female population that outnumbers the males, it means that development is not feasible without the socio economic participation of women. Promotion of women's entrepreneurship in MSMEs upholds novel entrepreneurial spirit, inclusive development and innovative resilience in the State for exploiting innovative economic opportunities and bringing new business to the region.

\section{References}

Ascher, J. (2012). Female entrepreneurship: An appropriate response to gender discrimination. Journal of Entrepreneurship and Innovation, 8(4), 97-114.

Behara, S. R., \& Niranjan, K. (2012). Rural women's entrepreneurship in India. International Journal of Computational Engineering \& Management, 15(6), 6-15.

Centre for Research Planning and Action. (2012). State level actions to promote growth of manufacturing (Resources and Capability Review). Thiruvananthapuram: Centre for Research Planning and Action (CRPA), Government of Kerala. Retrieved from http://www.ksidc.org/userfiles/ kerala_report.pdf

Department of Economics and Statistics. (2014). Gross domestic product of Kerala and India from 2004-05 to 2012-13 (Base Year 2004-05). Thiruvananthapuram: Department of Economics and Statistics (DES), Government of Kerala. Retrieved from http://www.ecostat.kerala.gov. in/docs/pdf/stateincome/2014/gdpreport0405to1213.pdf

Department of Industries and Commerce. (2015). Kerala industrial and commercial policy amended-2015. Thiruvananthapuram: Department of Industries and Commerce, Government of Kerala. Retrieved from 
http://foodprocessingindia.co.in/state_pdf/Kerala/Kerala-Industrial-\&Commercial-Policy-Amended-2015.pdf

Directorate of Industries and Commerce. (2014). District Industries Centre (DIC). New Delhi: National Information Centre (NIC), GOI.

Express News Service (2015, March 16). Kerala stands tall in overall development, says ASSOCHAM. The New Indian Express. Retrieved from http://www.newindianexpress.com/cities/kochi/2015/mar/16/KeralaStands-tall-in-Overall-Development -says-Assocham-729242.html

Express News Service (2015, May 08) Women's entrepreneurship mission to be launched today. The New Indian Express. Retrieved from http:// www.newindianexpress.com/states/kerala/2015/may/08/WomenEntrepreneurship-Mission-to-be-Launched-Today-757665.html

Gancarczyk, M., \& Zabala-Iturriagagoitia, J. M. (2015). The process of the growth of small and medium-sized enterprises (SMEs). Journal of Entrepreneurship and Innovation, 11(4), 3-24.

Gupta, R. \& Kumari, K. (2014). Women empowerment through entrepreneurship in India. AISECT University Journal, 3(5).

Kelly, D. J., Brush, C. G., Greene, P. G., \& Litovsky, Y. (2010). Global entrepreneurship monitor, 2010 report: Women entrepreneurs worldwide. United States: Babson College and the Global Entrepreneurship Research Association (GERA). Retrieved from http://www.espae.espol.edu.ec/ images/FTP/2010_GEM_Womens_Report.pdf

Lal, M. (2013). Inter-ministerial committee for accelerating manufacturing in Micro, Small \& Medium Enterprises sector. New Delhi: MSME, Government of India. Retrieved from http://msme.gov.in/Accelerating\%20Manufacturing\%20in\%20the\%20MSME\%20Sector.pdf

Luczka, T., \& Przepiora, P. (2012). Regional determinants of efficiency growth of small and medium-sized enterprises: Evidence from Poland. Journal of Entrepreneurship and Innovation 8(1), 138-154.

Micro Small and Medium Enterprises Development Institute. (2012). State profile of Kerala 2011-1, MSME DI, Thrissur, Ministry of MSME, Government of India. Thrissur: MSME DI, Government of Kerala. Retrieved from http://msmedithrissur.gov.in/secure/admin/writereaddata/Documents/STATE\%20PROFILE\%20OF\%20KERALA\%20\%20\%20\%20\%20\%20 2012cp12.pdf

Micro Small and Medium Enterprises Press Information Bureau. (2014, July 22). Contribution of MSMEs to GDP, exports and employment. New Delhi: Press Information Bureau (PIB), MSME, Government of India. Retrieved from http://pib.nic.in/newsite/PrintRelease.aspx?relid=107201

Micro Small and Medium Enterprises. (2014). MSME Annual Report, 201314. New Delhi: Ministry of MSME, Government of India. Retrieved from http://msme.gov.in/WriteReadData/DocumentFile/ANNUALREPORTMSME-2013-14P.pdf

Micro Small and Medium Enterprises. (2015). MSME Annual Report, 201415. New Delhi: Ministry of MSME, Government of India. Retrieved 
from http://msme.gov.in/WriteReadData/DocumentFile/MSME\%20 ANNUAL\%20REPORT\%202014-15_English.pdf

Micro Small and Medium Enterprises. (2016). MSME annual report, 201516. New Delhi: Ministry of MSME, Government of India. Retrieved from http://msme.gov.in/WriteReadData/DocumentFile/MEME\%20ANNUAL\%20REPORT\%202015-16\%20ENG.pdf

Ministry of Statistics and Programme Implementation (2014). Provisional results of sixth economic census, all India report. New Delhi: Ministry of Statistics and Programme Implementation (MOSPI), Central Statistical Office. Retrieved from http://mospi.nic.in/Mospi_New/upload/census_2012/sixth_ec_prov_result_30july14.pdf

Nair, T. K. A. (2010). Report of prime minister's task force on micro, small and medium enterprises. New Delhi: MSME, GOI. Retrieved from http:// msme.gov.in/pm_msme_task_force_jan2010.pdf

Nisha, K. M. (2015). Role of women's entrepreneurship in economic development of Kerala with special reference to microenterprises (Doctoral thesis). Department of Commerce, Aligarh Muslim University, India.

Reynolds, P. D., Camp, S. M., Bygrave, W. D., Autio, E., \& Hay, M. (2002). Global entrepreneurship monitor: 2001 summary report. London: London Business School and Babson College. Retrieved from ftp://ftp.zew.de/ pub/zew-docs/entrepreneurship/reynolds_summary.pdf

Shah, H. (2013). Creating anenabling environmentforwomen's entrepreneurship in India. ESCAP South and South-West Asia Office. Retrieved from http:// www.unescap.org/sites/default/files/ESCAP-SSWA-DevelopmentPaper_1304_1.pdf

State Planning Board Kerala. (2013). Twelfth five year plan 2012-17. Thiruvanathapuram: SPB, Government of Kerala. Retrieved from http:// www.keralabudgetwatch.org/wp-content/uploads/2013/08/12th_fyp_ ker.pdf

United Nations Industrial Development Organisation. (2003). A path out of poverty: Developing rural and women's entrepreneurship. Vienna: UNIDO Publication. Retrieved from https://www.scribd.com/ document/45856934/A-Path-Out-of-Poverty

Vijayakumar, T., \& Naresh, B. (2013). Women's entrepreneurship in India: Role of women in small and medium enterprises. Trans Asian Journal of Marketing \& Management Research 2(7), 13-25.

\section{Abstract (in Polish)}

Nowe tysiqclecie jest postrzegane jako epoka przedsiębiorczości z przedsiębiorcami dostrzegajqcymi nowe możliwości, organizujqcymi zasoby, podejmujqcymi ryzyka, aby realizować swoje cele w tworzeniu innowacyjnych przedsięwzięć i docieraniu do nowych horyzontów. Kobiety przedsiębiorcze majq siłę, aby stawić czoła licznym wyzwaniom, takich jak tworzenie kapitału, równowaga, zapewniajqca zrównoważony $i$ sprzyjajq̨cy włączeniu społecznemu rozwój społeczno-gospodarczy w zróżnicowanych 
gospodarkach, poprzez wykorzystanie ogromnych możliwości biznesowych we współczesnym świecie. Kerala, południowy stan Indii, przeżywa odnowienie gospodarcze dzięki transformacji technologicznej, a w szczególności poprzez wzrost liczby kobiet zorientowanych na mikro, małe i średnie przedsiębiorstwa (MMŚP). Badanie ma na celu: określenie tendencji wzrostowej przedsiębiorczości kobiet w mikroprzedsiębiorstwach w stanie Kerala; zbadanie, czy działania przedsiębiorczych kobiet znaczq̨co różniq się $w$ przedsiębiorstwach należq̨cych do kobiet, w zależności od rodzaju organizacji i charakteru działalności; a także zbadanie perspektyw $i$ wyzwań, przed którymi stojq kobiety przedsiębiorcze poprzez działania w zakresie mikroprzedsiębiorczości. Metoda badawcza polega na zastosowaniu opisowej analizy ilościowej danych wtórnych zebranych głównie z bazy danych Dyrekcji Przemysłu i Powiatowego Centrum Przemysłu w okresie 7 lat, rozciggajacym się od 2007-08 do lat 2013-14. Wyniki pokazujq, że MMŚP uzyskały lepszq dystrybucję dochodów, działajq̨ $w$ różnorodnych dziedzinach gospodarki z ograniczonym kapitałem, stworzenie większych możliwości zatrudnienia, a tym samym zmniejszenia ubóstwa i nierówności. Analiza tendencji odzwierciedla wzrost liczby przedsiębiorstw, inwestycji, zysków i możliwości zatrudnienia generowanych w szczególności poprzez mikroprzedsiębiorstwa kobiet. Odgrywajq one kluczowq rolę w gospodarce pod względem tworzenia miejsc pracy i generowania możliwości zatrudnienia dla innych. Zmiana paradygmatu jest postrzegana $w$ roli przedsiębiorczości kobiet $w$ zakresie innowacji, postaw, cech przywódczych, konkurencyjności, przedsiębiorczości $i$ umiejętności absorbowania nowych podmiotów na rynku pracy, aktywizujq̨c marginalizowane kobiety.

Słowa kluczowe: przedsiębiorczość kobiet, mikroprzedsiębiorstwa, mikroprzedsiębiorca, MMSP.

\section{Biographical notes}

Nisha. K.M. has completed her Ph.D. from Department of Commerce, Aligarh Muslim University Aligarh, India. She has published several research papers in the fields of Women's entrepreneurship, Micropreneurship, Agripreneurship, Ecopreneurship, Foreign Direct Investments, Consumer Behaviour etc, in journals of both national and international repute. She has also attended several national and international conferences, seminars and workshops. Besides this she has also completed her master's in education from University of Calicut, India.

Mohd Asif Khan is an Associate Professor of Department of Commerce, Aligarh Muslim University (AMU), Aligarh, India. He is a noble academician, an ardent social activist and above all a great philanthropist. Apart from being an eminent professor he has also been involved in administrative level activities of AMU by holding posts like proctor, provost, executive council member etc of 
the University. He has several publications in international and national journal specializing in areas like International Business, Entrepreneurial Development, and International Marketing. He has also attended several international and national conferences, seminars, symposiums, workshops etc. 
